\title{
DAUGIAKRITERINIS PROFESINIO MOKYMO KOKYBĖS VALDYMO VERTINIMO MODELIS
}

\author{
Daiva Andriušaitiené $\dot{e}^{1}$, Vanda Birutė Ginevičiené2 ${ }^{2}$ Algis Šileika ${ }^{3}$ \\ Vilniaus Gedimino technikos universitetas, Sauletekio al. 11, LT-10223 Vilnius, Lietuva \\ El.paštas: ${ }^{1}$ daiva.andriusaitiene@dsti.lt; ${ }^{3}$ algis.sileika@dsti.lt
}

Iteikta 2008-02-11; priimta 2008-03-04

\begin{abstract}
Santrauka. Kokios gi yra sudètingu socialiniu reiškinių, kuriems priklauso ir profesinio mokymo kokybės valdymas, kompleksinio kiekybinio vertinimo galimybès? Ar šio reiškinio kiekybiniam vertinimui tinka daugiakriteriniai metodai? Ar šie metodai tinka profesinio mokymo kokybės valdymo tyrimui ir stebėsenai? Šiame straipsnyje siekiama atsakyti $\mathfrak{i}$ minètuosius klausimus, pristatyti ir aptarti sukurtą profesinio mokymo kokybès valdymo daugiakriterinio vertinimo modeli bei kitus su profesinio mokymo kokybės valdymo daugiakriteriniu vertinimu susijusius klausimus. Be to, pristatant atliktos profesinio mokymo kokybès valdymo kiekybinio bandomojo ekspertinio vertinimo rezultatus, aptariama ekspertụ ịverčių suderinamumo problema, atliekamas profesinio mokymo įstaigų kokybès valdymo kriterijų reikšmingumo ir reikšmių ekspertinio vertinimo suderinamumo nustatymas, atliekamas šių mokyklų kokybès valdymo daugiakriterinis vertinimas, kurio pagrindu sudaroma prioritetinè jų eilè pagal darbo kokybę.
\end{abstract}

Reikšminiai žodžiai: profesinis mokymas, kokybės valdymas, daugiakriteriniai metodai.

\section{MULTICRITERIA MODEL FOR EVALUATING QUALITY MANAGEMENT OF PROFESSIONAL TRAINING}

\author{
Daiva Andriušaitienè $\dot{1}^{1}$ Vanda Birutė Ginevičiené2 ${ }^{2}$ Algis Šileika ${ }^{3}$ \\ Vilnius Gediminas Technical University, , Sauletekio al. 11, LT-10223 Vilnius, Lithuania \\ E-mail: ${ }^{1}$ daiva.andriusaitiene@dsti.lt; ${ }^{3}$ algis.sileika@dsti.lt \\ Received 11 February 2008; accepted 4 March 2008
}

\begin{abstract}
What are the possibilities of complex quantitative evaluation of complex social phenomena and professional training in particular? Can these methods be used for multicriteria evaluation of this phenomenon? Are they well-suited for investigation and monitoring of professional training quality management? The present paper aims at answering these questions, presenting and discussing the developed model of multicriteria evaluation of professional training quality management and considering other problems associated with multicriteria evaluation of quality management of professional training. Moreover, presenting the results of pilot quantitative expert evaluation of professional training quality management, the problem of consistency of expert estimates was discussed, the consistency of experts' estimates of weights and values of the criteria describing quality management of professional training institutions was determined and multicriteria evaluation of the quality of the above schools was made allowing their arrangement in the priority order according to the quality of performance.
\end{abstract}

Keywords: professional training, quality control, multicriteria methods. 


\section{Ivadas}

Ar profesinio mokymo kaip proceso bendraja prasme valdymas siekiamu tikslų požiūriu yra efektyvus? Ar profesinio mokymo įstaigos pakankamai tikslingai formuoja strateginius bei trumpo laikotarpio tikslus ir uždavinius? Ar pakankama valdymo lygmens darbuotojų kvalifikacija ir ar motyvuojama vadovus bei profesijos mokytojus kvalifikaciją tobulinti? Ar pasiekti rezultatai tenkina darbuotojus, mokinius, jụ tèvus, darbdavius, bendruomenę ir kitus socialinius partnerius? Kokie yra kokybès valdymo trūkumai ir kaip visa tai tobulinti? Siekiant atsakyti ị šiuos klausimus, reikia įvertinti profesinio mokymo kokybès valdymą charakterizuojančius rodiklius. Tačiau vienkartinis rodikliu ivertinimas nèra pakankamas, norint nustatyti tendencijas. Tam būtina sukurti profesinio mokymo kokybės valdymo stebėsenos sistemą.

Europoje priimta EFQM rekomenduojamų kokybès valdymo kriteriju sistema. Tačiau šiais devyniais kriterijais neimanoma tiksliai ir taikliai ivertinti tokio plataus bei sudetingo tyrimo objekto kaip profesinio mokymo kokybès valdymas. Todèl jais (kaip pagrindu) remiantis, buvo suformuota Lietuvos profesinio mokymo kokybès valdymą atspindinčių kriterijų hierarchinè sistema, kurią sudaro minètieji devyni pagrindiniai EFQM kriterijai, papildyti daliniais kriterijais. Kriterijai ir daliniai kriterijai savo ruožtu yra išskaidyti i pirminius kriterijus. Ši suformuota hierarchiné profesinio mokymo kokybės valdymo kriteriju sistema tapo profesinio mokymo kokybès valdymo vertinimo sistemos matematinio modelio konstravimo pagrindu, pagal kurị ir buvo atliktas bandomasis tyrimas.

\section{Sudėtingų socialinių reiškinių kompleksinis kiekybinis vertinimas}

Pastaruoju metu vertinama sudetingu reiškinių, o tokiems priklauso ir socialiniai, kiekybiniam vertinimui plačiai taikomi daugiakriteriniai metodai. Neatsižvelgiant i nagrinejjamą sritị, šiam vertinimui būdingi tam tikri etapai - pradedant nuo tyrimo problemos formulavimo, tyrimo objekto bei tikslu nustatymo ir baigiant tiriamos reiškinị apibendrinančios kiekybinès išraiškos nustatymu ir gautų rezultatų analize (1 pav.) (Ginevičius, Podvezko 2005).

Pirmuoju etapu yra identifikuojamas tyrimo objektas, suformuluojami tyrimo tikslai. Aptariamuoju atveju tyrimo objektas yra profesinio mokymo ịstaigu kokybès valdymas, o tyrimo tikslas - mokymo įstaigų darbo kokybès valdymo srityje kiekybinis ịvertinimas, siekiant visas profesines mokymo institucijas suranguoti prioritetine tvarka.

Antruoju etapu identifikuojami visi veiksniai, galintys paveikti nagrinèjamą objektą tyrimo tikslų aspektu. Jis sudaromas remiantis literatūros šaltinių analize, taip pat ekspertų apklausos būdu (Ginevičius, Podvezko 2005).

Trečiuoju etapu, remiantis suformuotu veiksnių sąrašu, sudaroma tiriamo reiškinio veiksnių sistema. Suformuota tiriamo reiškinio veiksnių sistema yra daugiakriterinio vertinimo pagrindas.

Ketvirtuoju etapu suformuojami sistemos veiksnius atspindintys rodikliai, t. y. veiksniams suteikiama formalizuota išraiška. Tai gali būti išreikšta analitinèmis formulèmis arba balų sistemomis (sunkiai formalizuojamiems veiksniams).

Penktuoju etapu vienu metu atliekami du veiksmai: tiriamo reiškinio veiksnių reikšmių nustatymas ir tiriamo reiškinio veiksnių reikšmingumo nustatymo modelio parinkimas. Tiriamo reiškinio rodiklių reikšmès gali būti nustatytos dvejopai. Vienu atveju, jeigu yra tokia galimybé, jos imamos iš ataskaitu ar kitų statistinių šaltiniu, kitu atveju, jeigu tokios galimybės nèra, - nustatomos balais, remiantis pasirinkta vertinimo skale. Paprastai tai atlieka ekspertai. Tiriamo reiškinio veiksnių reikšmingumo nustatymo modelio parinkimas priklauso nuo daugelio aplinkybiu - kiek veiksnių sudaro sistemą, kokio lygmens galima suformuoti ekspertų komandą ir pan. (Ginevičius, Podvezko 2005).

Šeštuoju etapu vienu metu atliekami taip pat du veiksmai: tiriamo reiškinio rodiklių reikšmių normalizavimas ir tiriamo reiškinio veiksnių reikšmingumo nustatymas. Normalizavimas - visų rodiklių reikšmių pavertimas bedimensiais (tarpusavyje palyginamais) atitinkamai juos transformuojant. Bet kokiu atveju tiriamo reiškinio veiksnių reikšmingumą, nepriklausomai nuo pasirinkto būdo, nustato ekspertai, todèl neatskiriama šio vertinimo dalis yra ekspertų nuomonių suderinamumo nustatymas.

Septintasis etapas - tiriamo reiškinio rodiklių sujungimo ¡̇ apibendrinantị dydị būdo parinkimas. Galimi du atvejai. Pirmas, kai iš visų esamu parenkamas, tyrejjų nuomone, tinkamiausias daugiakriterinio vertinimo būdas. Šiuo atveju padèti komplikuoja tai, kad nei teorija, nei praktika kol kas neatsake i klausimus - kuo vienas vertinimo būdas geresnis už kitą ir kuris iš jų yra tikslesnis bei kada tikslinga taikyti būtent tą, o ne kita būdą ir pan. Todèl prasmingas kitas kelias, kai daugiakriterinis vertinimas atliekamas keliais būdais ir po to imamas vertinimų vidurkis (Ginevičius, Podvezko 2001,2003, 2004a, b; Zavadskas et al.2004; Hokkannen, Salminen 1997; Ginevičius et al.2004; Бешелев, Гурвич 1974; Евланов 1984). Manoma, kad tokiu atveju bent iš dalies eliminuojami atskirų vertinimo būdụ trūkumai ir objektyvizuojami galutiniai rezultatai.

Aštuntuoju etapu tiriamo reiškinio rodikliai sujungiami $\mathfrak{i}$ apibendrinamaji dydị: atliekami praktiški daugiakriterinio vertinimo skaičiavimai pagal pasirinktą daugiakriterinio vertinimo būdą.

Devintuoju etapu atliekama gautų rezultatų analizè ir priimami sprendimai dèl nagrinèjamo reiškinio būsenos 
pagerinimo. Šios analizès metu nustatoma, dèl ko vienos institucijos atsidūrè prioritetinès eilès gale, kitos - priekyje. Analizuojamos stipriosios lyderių pusés ir rengiamos rekomendacijos blogiau dirbančioms institucijoms.

Taigi profesinio mokymo kokybès valdymo daugiakriterinio vertinimo pagrindu tapo aptartoji tiriamo reiškinio kompleksinio daugiakriterinio vertinimo sistema (1 pav.) ir EFQM rekomenduojamų rodiklių pagrindu suformuota hierarchine rodikliu sistema (2 pav.). Ši suformuota hierarchine profesinio mokymo kokybès valdymo kriteriju sistema tapo pagrindu profesinio mokymo kokybès valdy- mo vertinimo sistemos matematiniam modeliui konstruoti, po kurio buvo atliktas profesinio mokymo kokybès valdymo kiekybinis bandomasis ekspertinis vertinimas.

Tuo tikslu pirmiausia aptarta ekspertų kriterijų reikšmingumo įverčių suderinamumo problema. Paskui atliktas profesinio mokymo ịstaigu kokybės valdymo kriteriju reikšmingumo ir reikšmių ekspertinio vertinimo suderinamumo nustatymas. Galiausiai atliktas šiu mokyklu kokybès valdymo daugiakriterinis vertinimas, kurio pagrindu sudaryta prioritetinè eilè pagal ju darbo kokybę profesinio mokymo kokybès valdymo aspektu.

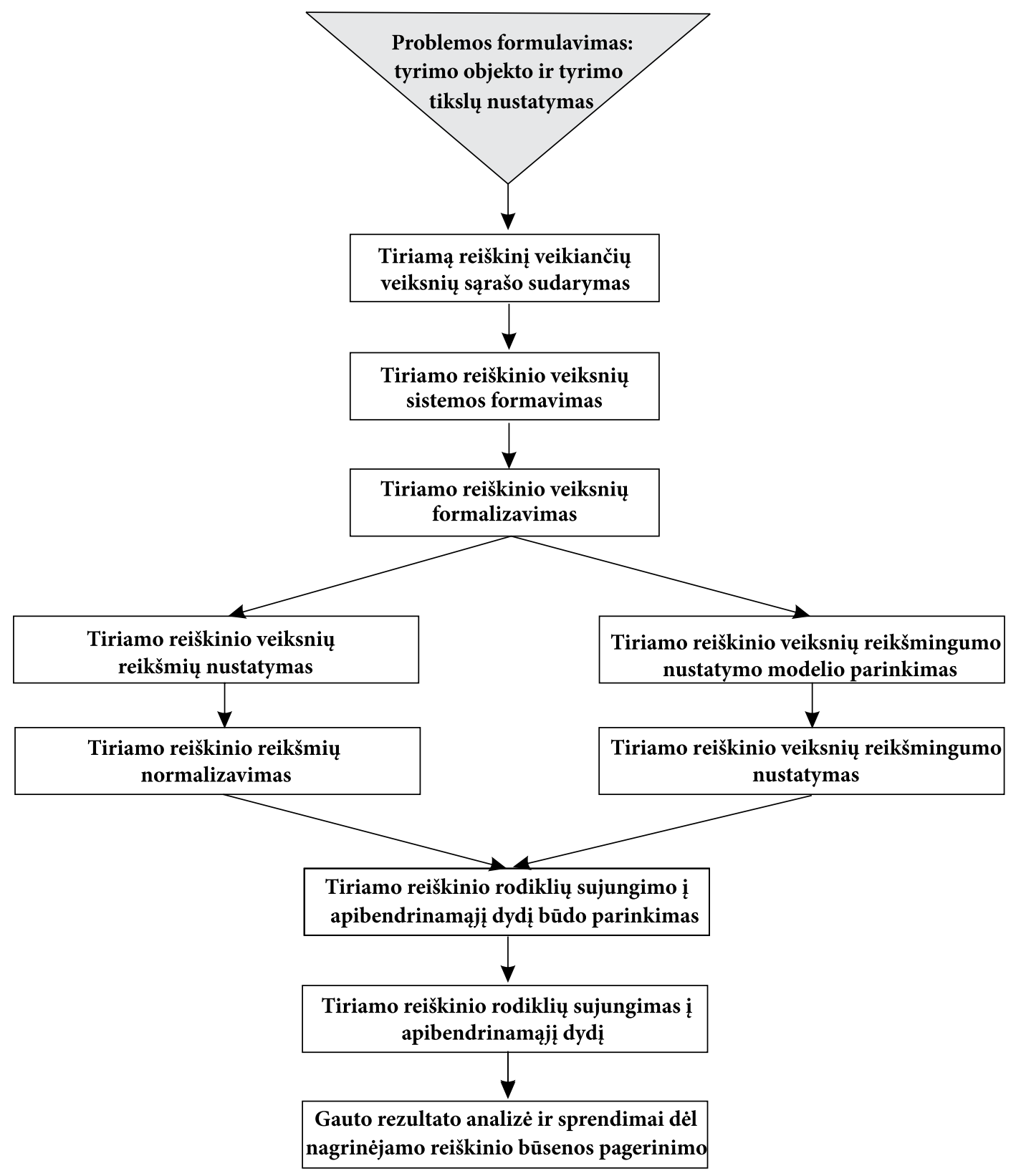

1 pav. Tiriamo reiškinio kompleksinio daugiakriterinio vertinimo ir jo rezultatų naudojimo etapai

Fig. 1. The stages of complex multicriteria evaluation of the investigated phenomena and application of the results obtained 


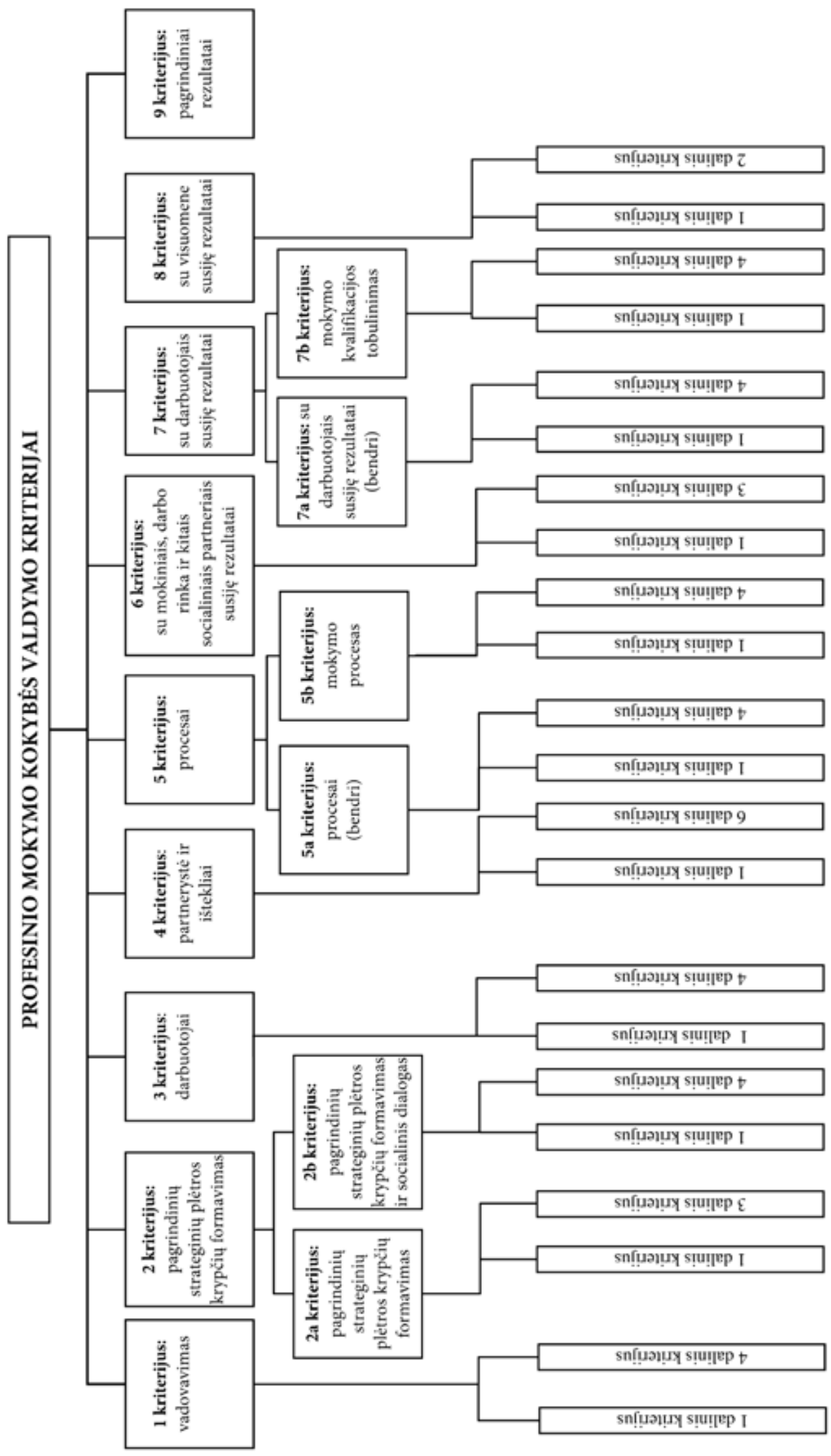




\section{Tiriamo reiškinio veiksnių reikšmingumo nustatymo būdai}

Rodiklių svorių reikšmių nustatymo metodai priskiriami subjektyviems, jeigu vertinimo pagrindas yra specialistu (ekspertu) nuomonès (Ginevičius, Podvezko 2001, 2003, 2004a, b; Zavadskas et al. 2004; Бешелев, Гурвич 1974; Евланов) ir objektyviems, jei konkrečios svoriu reikšmés priklauso nuo rodiklių duomenų masyvo struktūros (Ustinovičius 2001a, b; Hwang, Yoon 1981). Be to, gali būti apibendrinti, integruotai sujungti subjektyvūs ir objektyvūs svoriai (Fan et al 1977; Завадскас 1991; Ustinovičius 2001a, b; Ginevičius, Gudačiauskas 2004). Iš triju minètu pagrindinis yra subjektyvus ịvertinimas, tačiau tam būtina aukšta specialistų (ekspertų) kvalifikacija, nes nuo to priklauso ju vertinimo tikslumas. Be to, nesant tinkamai ju kvalifikacijai, gali būti gauti prieštaringi rezultatai, todèl rodiklių svorius daugiakriteriniam vertinimui galima pritaikyti, jei nustatytas ekspertu vertinimo suderinamumo laipsnis (Podvezko 2005). Jị nustato konkordancijos koeficientas, skaičiuojamas lyginamujų objektų rangavimo pagrindu. Ekspertų vertinimų rezultatas yra matrica, $E=\left\|e_{i j}\right\|(i=1, \ldots, m ; j=1, \ldots, r)$ čia $m$ - lyginamų rodikliu (objektų) skaičius, $r$ - ekspertų skaičius. Ekspertai gali vertinti laukiamą rodiklio reikšmę skirtingu būdu. Vertinti gali būti pritaikyta bet kokia matavimo skalè, pavyzdžiui, rodiklio vienetais, procentais, vieneto dalimis, pagal dešimties balu sistemą arba porinio palyginimo Saaty skalę. Tačiau dispersiniam konkordancijos koeficientui skaičiuoti tinka tik ekspertų rodiklių rangavimas. Jei ekspertų vertinimai buvo bet kokio kitokio pavidalo, juos preliminariai reikia ranguoti. Rangavimas yra procedūra, kai pačiam svarbiausiam rodikliui suteikiamas rangas, lygus vienetui, antram pagal svarbumą - rangas du ir t. t., paskutiniam pagal svarbumą - rangas $m$; čia $m$ - lyginamų rodiklių skaičius. Ekvivalentiniams rodikliams suteikiama vienoda reikšmè - eilinių rangu aritmetinis vidurkis. Tada, jeigu eilès tvarka dviem rodikliams rangai būtų, pavyzdžiui, 4 ir 5, bet rodiklių svarbumas, kaip mano ekspertas, vienodas, tai jiems abiem suteikiamas vienodas rangas 4, 5; Jeigu eilès tvarka trys ekvivalentūs rodikliai turètų rangus 7,8 , ir 9 , tai jiems visiems suteikiamas vienodas rangas $(7+8+9) / 3=8$.

Dispersinį konkordancijos koeficientą apibrèžè M. Kendall (Евланов 1984). Koeficiento idèja susieta su kiekvieno rodiklio rangų suma visų ekspertų atžvilgiu

$$
e_{i}=\sum_{j=1}^{r} r_{i j}(i=1, \ldots, m)
$$

Tiksliau, su dydžių $e_{j}$ nukrypimu nuo bendro vidurkio $\bar{e}$ kvadratų suma $S$ (dispersijos analogas):

$$
S=\sum_{i=1}^{m}\left(e_{i}-\bar{e}\right)^{2} .
$$

Bendras vidurkis e e skaičiuojamas pagal šią formulę:

$$
\bar{e}=\frac{\sum_{i=1}^{m} e_{i}}{m}=\frac{\sum_{i=1}^{m} \sum_{j=1}^{r} e_{i}}{m} .
$$

Pažymëjus faktišką kvadratų sumos rodiklių vidurkių nukrypimą nuo bendro vidurkio, suskaičiuotą pagal formulę (2), raide $S$, konkordancijos koeficientas apibrèžiamas suskaičiuotos $S$ ir atitinkamos didžiausios $S_{\max }$ santykiu:

$$
W=\frac{12 S}{r^{2} m\left(m^{2}-1\right)} .
$$

Jei ekspertu nuomonès suderintos, konkordancijos koeficiento $W$ reikšmè arti vieneto, jei vertinimai labai skiriasi, $W$ reikšmè arti nulio.

Konkordancijos koeficientas gali būti taikomas praktikoje, jei nustatyta jo ribinè reikšmé, kada ekspertų vertinimus dar yra suderintais. M. Kendall įrode (Евланов 1984), kad jeigu objektų skaičius $m>7$, konkordancijos koeficiento reikšmingumas gali būti nustatytas, naudojant $\chi^{2}$ kriteriju. Atsitiktinis dydis

$$
\chi^{2}=W r(m-1)=\frac{12 S}{r m(m+1)}
$$

pasiskirstęs pagal $\chi^{2}$ skirstinị su $v=m-1$ laisvès laipsniu. Pagal pasirinktą reikšmingumo lygmenị $\alpha$ (praktikoje $\alpha$ reikšmé paprastai 0,05 arba 0,01 ) iš $\chi^{2}$ skirstinio lentelès su $v=m-1$ laisvès laipsniu radome kritinę reikšmę $\chi_{k r}^{2}$. Jei suskaičiuota pagal (5) formulę $\chi^{2}$ reikšmè didesnè už $\chi_{k r}^{2}$, tai išeina, kad ekspertų vertinimai yra suderinti.

Isitikinus, kad ekspertu nuomonés yra suderintos, pereinama prie rodiklių reikšmingumo nustatymo. Kai vertinimų rodikliu yra daug, dažniausiai taikomas porinio palyginimo (subjektyvus) T. Saaty metodas (Hwang, Lin 1987; Saaty 1994). Kai vertinama nedaug rodikliu taikomas paprastesnis, vadinamasis tiesioginis nuomoniu reikšmingumo nustatytmo būdas, kai ekspertai vieneto dalimis nurodo kiekvieno rodiklio svarumą nagrinëjamo reiškinio atžvilgiu (Ginevičius, Gudačiauskas 2004).

\section{Taikytų profesinio mokymo kokybès valdymo daugiakriterinio vertinimo metodų apžvalga}

Sudètinių dydžiu veiklos efektyvumui nustatyti taikomi ivvairūs kokybinio ir kiekybinio daugiakriterinio kompleksinio i̇vertinimo metodai (Завадскас 1991; Ustinovičius 2001a, b; Hwang, Yoon 1981; Hwang, Lin 1987; Saaty 1980, 1994; Ginevičius, Gudačiauskas 2004; Beuthe, Scannella 2001). Šiuo metu sukurta ir taikoma daug sudètinių dydžiu veiklos efektyvumo kompleksinio ivertinimo metodu. Kokybiniai metodai, remiantis specialistų (ekspertụ) nuomonėmis, nustato vieną geriausiu iš pasiūlytu alternatyvų arba keletą iš geriausiu alternatyvu (Hokkannen, Salminen 1997; Ginevičius, Podvezko 2001, 2003; Ginevičius et al. 2004, Бешелев, Гурвич 
1974; Евланов 1984, Fan et al. 1977; Завадскас 1991; Ustinovičius 2001a, b; Hwang, Yoon 1981; Hwang, Lin 1987; Saaty 1980, 1994; Ginevičius, Gudačiauskas 2004; beuthe, Scannella 2001; Brans et al. 1986; Opricovič, Tzeng 2004; Roy 1996; Zavadskas, Kaklauskas 1996; Larichov, Moshkovich 1977; Ларичев 1979). Kiekybiniai metodai kiekybiškai ịvertina kiekvieną alternatyvą ir nustato dydžių skirtumus tarp vertinimų alternatyvų. Kiekvienas metodas turi savo privalumą ir išryškina (akcentuoja) atskiras šių dydžių ypatybes. Dauguma metodų naudoja pradinių duomenų (rodiklių reikšmès) skirtingą normalizaciją arba duomenų transformaciją.

Kiekybinių metodų pagrindą sudaro rodiklių, charakterizuojančių lyginamų objektų, statistinių duomenu arba ekspertų vertinimų matrica $R=\left\|r_{i j}\right\|, i=1, \ldots, m$; $j=1, \ldots, n$, čia $m$ - rodiklių skaičius, $n$ - lyginamų objektų (alternatyvų) skaičius. Praktiškai nè vieno metodo negalima pritaikyti formaliai, iš karto. Kiekvienas metodas turi savo pranašumų.

Taikant kiekybinius daugiakriterinius įvertinimo metodus reikia nustatyti, kokio pavidalo - maksimizuojamojo arba minimizuojamojo - yra kiekvienas rodiklis. Maksimizuojamujų (mažoruojamujų) rodiklių geriausios reikšmès yra didžiausios, minimizuojamuju (minoruojamų) rodiklių geriausios reikšmès yra mažiausios. Dauguma metodų naudoja pradinių duomenų (rodiklių reikšmès) skirtingą specifinę normalizaciją arba duomenu transformaciją. Metodai skiriasi pagal savo sudetingumą.

Šiame darbe taikyti paprasčiausi daugiakriterinio ịvertinimo metodai - vietų suma, SAW.

1. Visų rodiklių vietų suma $(V S) \mathrm{V}_{j}$ kiekvienam j-ajam objektui. Ji nustatoma pagal formulę (Ginevičius, Podvezko 2001, 2003; Ginevičius et al. 2004):

$$
V_{j}=\sum_{i=1}^{m} m_{i j},
$$

čia $m_{i j}-i$-tojo rodiklio vieta $j$-ajam objektui $\left(1 \leq m_{i j} \leq m\right)$. Iš (6) formulès išeina, kad geriausią $V_{j}$ reikšmę turèsime tada, kai ji bus mažiausia. Jeigu kelios $m_{i j}$ reikšmès sutampa, kiekvienam objektui priskiriama ta pati reikšmé (vieta) - jų aritmetinis vidurkis. Pavyzdžiui, jeigu trims objektams pagal $i$-taji rodikli teko tokia pati vieta ir pagal eiliškumą jie užèmè 4,5 ir 6 vietas, tai jiems suteikiama tokia pati reikšmé (vieta) $m_{i j}=5$. Jeigu vienodos $i$-tojo rodiklio reikšmès tenka, pavyzdžiui, 9 ir 10 vietoms, tai šiems objektams priskiriama reikšmè 9,5 . Kriterijaus $V_{\mathrm{j}}$ reikšmės nepriklauso nei nuo pradinių duomenų normalizavimo būdo, nei nuo jų skalès transformavimo, nei nuo rodiklių svorių $\omega_{i}$ reikšmių $(i=1$, $\ldots, m)$. Bet būtina metodo taikymo sąlyga yra išankstinis maksimizuojamujų arba minimizuojamujų rodiklių charakterio išankstinis nustatymas. Arba galima, pavyzdžiui, pertvarkyti minimizuojamuosius rodikliụ ị maksimizuojamuosius pagal formulę:

$$
\bar{r}_{i j}=\frac{\min r_{i j}}{r_{i j}},
$$

čia $r_{i j}$ - $i$-ojo rodiklio reikšmè $j$-ajam objektui, tada pati mažiausia rodiklio reikšmè igis didžiausią reikšmę, lygią vienetui.

Skaičiavimai rodo, kad šis kriterijus yra pats paprasčiausias ir ji taikyti tikslinga tik pradiniam apytikriam ivvertinimui, nors dažnai VS metodo rezultatai mažai skiriasi nuo sudètingų matematinių metodų.

2. SAW (Simple Additive Weighting) metodas. Skaičiuojama visų rodiklių pasvertų normalizuotų reikšmių suma $S_{j}$ kiekvienam $j$-ajam objektui. Ji nustatoma pagal formulę (Ginevičius et al. 2004; Hwang, Yoon 1981):

$$
S_{j}=\sum_{i=1}^{m} \omega_{i} \tilde{r}_{i j},
$$

čia: $\omega_{\mathrm{i}}-i$-tojo rodiklio svoris; $\tilde{r}_{i j}-i$-tojo rodiklio normalizuota reikšmè $j$-ajam objektui.

Pradiniai duomenys normalizuojami šiuo atveju pagal formulę (Завадскас 1991; Hwang Yoon 1981):

$$
\bar{r}_{i j}=\frac{r_{i j}}{\sum_{i=1}^{n} r_{i j}},
$$

čia $r_{i j}-i$-tojo rodiklio reikšmé $j$-ajam objektui.

Apytikriai skaičiuojant galima daryti prielaidą, kad visų rodiklių svoriai yra vienodi, t. y. $\omega_{i}=\frac{1}{16}=0,0625$. Geriausią kriterijaus $S_{j}$ reikšmę turèsime tada, kai ji bus didžiausia.

\section{Profesinio mokymo kokybès valdymo rodiklių reikšmingumo nustatymo rezultatai}

Remiantis profesinio mokymo kokybès valdymo stebèsenos vertinimo matematiniam modeliui sudaryti naudotinų tiriamojo reiškinio veiksnių reikšmingumo nustatymo būdų ir metodų analizès rezultatais, sukurtas tyrimo modelis, kurio pagrindiniai etapai atitinka aptartają daugiakriterinio vertinimo logiką. Numatyti ir atlikti šie konkretūs tyrimo žingsniai:

1. Ekspertinio vertinimo metu ịvertinamas kiekvieno iš suformuotos profesinio mokymo kokybès veiksnių sistemos veiksnio - būsimo kriterijaus reikšmingumas: nustatomi žemiausio hierarchinio lygio (dalinių kriterijų) ir pagrindinių kriterijų svoriai ir reikšmès.

2. Suformuota profesinio mokymo kokybės valdymo veiksnių sistema paverčiama ją atitinkančia kriteriju (rodiklių) sistema. Veiksnių sistemą sudaro devyni kriterijai ir kiekvieną ją detalizuojantys daliniai rodikliai. Kiekvienas iš veiksnių transformuojamas $\mathfrak{i}$ kriteriju (rodiklį).

3. Profesinio mokymo kokybès valdymas vertinamas 
apklausiant ekspertus, kompetentingus ịvertinti mokymo įstaigas jų veiklos kokybės valdymo aspektu.

4. Daugiakriteriniais metodais pagal nustatytuosius kriterijų ir dalinių kriterijų svorius bei konkrečioje mokymo įstaigoje deklaruotas kriterijus ir dalinius kriterijus atspindinčias rodiklių reikšmes gauti duomenys suvedami ir, remiantis pateiktuoju matematiniu modeliu, apibendrinami $\mathfrak{i}$ vieną dydị - skaičiu, kiekybiškai atspindintị nagrinèjamos profesinio mokymo institucijos mokymo kokybès valdymo kokybę.

\section{Mokymo istaigos suranguojamos.}

Pagal pristatytajị tyrimo modelị atliktas bandomasis tyrimas. Pirmiausia, remiantis (4) ir (5) formulemis, buvo patikrintas ekspertų nuomonių suderinamumas. Paskui tiesioginiu būdu nustatytas profesinio mokymo kokybès valdymą išreiškiančių rodiklių reikšmingumas. Skaičiuoti taikytieji rodiklių reikšmingumo koeficientai yra tokie pat visoms tiriamoms profesinio mokymo įstaigoms. Jie apskaičiuoti pagal suformuotos jungtinès ekspertų grupès ekspertinès apklausos duomenis (ekspertų grupę sudarè visų tiriamų septynių mokyklų atstovai).

\section{Profesinio mokymo ịstaigų kokybès valdymo daugiakriterinio įvertinimo rezultatai}

Profesinio mokymo kokybės valdymo rodiklių reikšmes kiekvienai mokyklai vertino konkrečios mokyklos ekspertai.

Nagrinejamų profesinio mokymo mokyklų kokybės valdymo daugiakriterinis vertinimas buvo atliktas keliais etapais, remiantis suformuota hierarchine rodiklių sistema (1 pav.).

1 etapas. Vertinti pradèta nuo hierarchinès rodiklių sistemos žemiausio (trečio) lygmens - pirmiausia nustatytos antro lygmens kriterijų (2a, 2b, 5a, 5b, 7a ir $7 \mathrm{~b})$ reikšmès. Jos nustatytos remiantis SAW metodu.

2 etapas. Šio etapo skaičiavimų rezultatas yra visų devynių pirmojo lygmens rodiklių reikšmès. Tuo tikslu, taikant SAW metodą, atlikti šie skaičiavimai: siekiant surasti 1 kriterijaus reikšmę, sujungti keturi žemiausio (trečio) lygmens daliniai rodikliai; antrojo kriterijaus - sujungti kriterijai 2a ir 2b (1 lentelè); trečiojo kriterijaus - žemiausio (trečio) lygmens keturi daliniai rodikliai; ketvirtojo kriterijaus - to paties lygmens šeši daliniai rodikliai; penktojo kriterijaus - antro lygmens kriterijai 5a ir 5b (2 lentelè); šešto kriterijaus - žemiausio (trečio) lygmens trys daliniai rodikliai; septinto kriterijaus - antro lygmens kriterijai 7a ir $7 \mathrm{~b}$ (3 lentelè); aštunto kriterijaus - žemiausio (trečio) lygmens du daliniai rodikliai (2 pav.).

1 lentelè. Dalinių rodiklių 2a ir $2 \mathrm{~b}$ daugiakriterinio vertinimo rezultatai

Table 1. Results of multicriteria evaluation of the subcriteria $2 \mathrm{a}$ and $2 \mathrm{~b}$

\begin{tabular}{cccccccc}
\hline & $\mathbf{1}$ & $\mathbf{2}$ & $\mathbf{3}$ & $\mathbf{4}$ & $\mathbf{5}$ & $\mathbf{6}$ & $\mathbf{7}$ \\
\hline 2a & 0,1420 & 0,1627 & 0,0622 & 0,1818 & 0,1558 & 0,1883 & 0,1072 \\
\hline $\mathbf{2 b}$ & 0,1295 & 0,1525 & 0,1202 & 0,1955 & 0,1525 & 0,1202 & 0,1295 \\
\hline
\end{tabular}

2 lentelè. Dalinių rodiklių $5 \mathrm{a}$ ir $5 \mathrm{~b}$ daugiakriterinio vertinimo rezultatai

Table 2. Results of multicriteria evaluation of the subcriteria $5 a$ and $5 b$

\begin{tabular}{cccccccc}
\hline & $\mathbf{1}$ & $\mathbf{2}$ & $\mathbf{3}$ & $\mathbf{4}$ & $\mathbf{5}$ & $\mathbf{6}$ & $\mathbf{7}$ \\
\hline $\mathbf{5 a}$ & 0,1329 & 0,1489 & 0,1397 & 0,1865 & 0,1505 & 0,1255 & 0,1160 \\
\hline $\mathbf{5 b}$ & 0,0978 & 0,1624 & 0,0975 & 0,1893 & 0,1676 & 0,1694 & 0,1160 \\
\hline
\end{tabular}

3 lentelè. Dalinių rodiklių $7 \mathrm{a}$ ir $7 \mathrm{~b}$ daugiakriterinio vertinimo rezultatai

Table 3. Results of multicriteria evaluation of the subcriteria $7 \mathrm{a}$ and $7 \mathrm{~b}$

\begin{tabular}{llllllll}
\hline & $\mathbf{1}$ & $\mathbf{2}$ & $\mathbf{3}$ & $\mathbf{4}$ & $\mathbf{5}$ & $\mathbf{6}$ & $\mathbf{7}$ \\
\hline $\mathbf{7 a}$ & 0,1355 & 0,1676 & 0,1033 & 0,1605 & 0,1921 & 0,1207 & 0,1203 \\
\hline $\mathbf{7 b}$ & 0,1375 & 0,1474 & 0,1110 & 0,1735 & 0,1735 & 0,1561 & 0,1040 \\
\hline
\end{tabular}

4 lentelè. Nagrinèjamų mokyklų pirmojo lygmens kriteriju reikšmių skaičiavimo rezultatai

Table 4. The calculation results of the 1 st level criteria values of the considered schools

\begin{tabular}{|c|c|c|c|c|c|c|c|}
\hline \multirow{2}{*}{ Rodiklis } & \multicolumn{7}{|c|}{ Mokymo ịstaiga } \\
\hline & 1 & 2 & 3 & 4 & 5 & 6 & 7 \\
\hline 1 & 0,1234 & 0,1759 & 0,1096 & 0,1926 & 0,1460 & 0,1629 & 0,0896 \\
\hline Vietos & 5 & 2 & 6 & 1 & 4 & 3 & 7 \\
\hline 2 & 0,1367 & 0,1584 & 0,0869 & 0,1876 & 0,1544 & 0,1594 & 0,1167 \\
\hline Vietos & 5 & 3 & 7 & 1 & 4 & 2 & 6 \\
\hline 3 & 0,1324 & 0,1595 & 0,1351 & 0,2031 & 0,1468 & 0,0879 & 0,1352 \\
\hline Vietos & 6 & 2 & 5 & 1 & 3 & 7 & 4 \\
\hline 4 & 0,0839 & 0,1656 & 0,1526 & 0,2127 & 0,1612 & 0,1317 & 0,0922 \\
\hline Vietos & 7 & 2 & 4 & 1 & 3 & 5 & 6 \\
\hline 5 & 0,1180 & 0,1546 & 0,1218 & 0,1877 & 0,1578 & 0,1458 & 0,1160 \\
\hline Vietos & 6 & 3 & 5 & 1 & 2 & 4 & 7 \\
\hline 6 & 0,1385 & 0,1480 & 0,0663 & 0,2039 & 0,1470 & 0,1320 & 0,1642 \\
\hline Vietos & 5 & 3 & 7 & 1 & 4 & 6 & 2 \\
\hline 7 & 0,1364 & 0,1562 & 0,1074 & 0,1674 & 0,1816 & 0,1399 & 0,1112 \\
\hline Vietos & 5 & 3 & 7 & 2 & 1 & 4 & 6 \\
\hline 8 & 0,1531 & 0,1531 & 0,1107 & 0,2158 & 0,1569 & 0,0997 & 0,1107 \\
\hline Vietos & 3,5 & 3,5 & 5,5 & 1 & 2 & 7 & 5,5 \\
\hline 9 & 0,1429 & 0,1633 & 0,0816 & 0,1429 & 0,1837 & 0,1633 & 0,1224 \\
\hline Vietos & 4,5 & 2,5 & 7 & 4,5 & 1 & 2,5 & 6 \\
\hline
\end{tabular}

5 lentelè. Nagrinètų profesinio mokymo mokyklų kokybès 
reitingavimo rezultatai

Table 5. The results of rating the considered professional schools according to the quality of performance

\begin{tabular}{lccccccc}
\hline & $\mathbf{1}$ & $\mathbf{2}$ & $\mathbf{3}$ & $\mathbf{4}$ & $\mathbf{5}$ & $\mathbf{6}$ & $\mathbf{7}$ \\
\hline SAW & 0,1265 & 0,1619 & 0,1139 & 0,1927 & 0,1550 & 0,1346 & 0,1154 \\
\hline Vietos & 5 & 2 & 7 & 1 & 3 & 4 & 6 \\
\hline Vietu suma & 47 & 24 & 53,5 & 13,5 & 24 & 40,5 & 49,5 \\
\hline Vietos & 5 & $2-3$ & 7 & 1 & $2-3$ & 4 & 6 \\
\hline $\begin{array}{l}\text { Bendra vietu } \\
\text { suma }\end{array}$ & 10 & 4,5 & 14 & 2 & 5,5 & 8 & 12 \\
\hline Bendra vieta & 5 & 2 & 7 & 1 & 3 & 4 & 6 \\
\hline
\end{tabular}

Devintojo kriterijaus reikšmè jau turima. Skaičiavimu rezultatai parodyti 4 lentelèje.

3 etapas. Šio etapo skaičiavimo rezultatas - nagrinèjamų mokyklų kokybės valdymo kriterijaus reikšmès. Ju pagrindu sudaroma šių mokyklų prioritetinè eilè (5 lentelè). Palyginimui prioritetinè eilè sudaryta ir pagal kitą daugiakriterinio vertinimo būdą - vietų sumą.

Iš 5 lentelès matyti, kad abiem atvejais, t. y. vertinant tiek SAW metodu, tiek pagal vietu sumą, skaičiavimo rezultatai beveik sutampa.

\section{Išvados}

Atliktas profesinio mokymo mokyklų kokybès valdymo daugiakriterinis vertinimas leidžia padaryti šias pagrindines išvadas:

1. Profesinio mokymo mokyklu kokybès valdymas sudètinga, kompleksinè problema, todèl šio fenomeno negalima išreikšti kokiu nors vienu rodikliu. Reikalingi ịvertinimo būdai, kurie galètų aprépti visą realybejje pasireiškiančia aspektų visumą. Analizè parodè, kad tam tinka daugiakriterinio vertinimo metodai.

2. Siekiant visapusiškai išanalizuoti profesinio mokymo istaigu kokybės valdymą, reikia suformuoti rodikliu sistemą. Analizè parodé, kad šiuo metu Europos Sajungos valstybėse taikoma organizaciju kokybès valdymo sistema EFQM yra netiksli todèl, kad apima tik devynis pagrindinius kriterijus, išreiškiančius esmines nagrinėjamo reiškinio puses. Šie kriterijai yra labai platūs, todèl vargu ar galima vien jais remiantis gana tiksliai ịvertinti nagrinejjamą reiškinị. Todèl buvo pasiūlyta hierarchinè rodikliu sistema, sudaryta detalizuojant kiekvieną iš minètų devynių kriteriju.

3. Duomenis, reikalingus daugiakriteriniam ịvertinimui, sudaro kriterijų reikšmingumai ir reikšmès. Nustatant tiek pirmuosius, tiek antruosius pasitelkiami ekspertai, todèl būtinas ju nuomonių suderinamumo patikrinimas. Šis tyrimo modelis taikytas ir atliktam bandomajam profesinio mokymo kokybès valdymo tyrimui.

4. Atlikti skaičiavimai pagal suformuotą hierarchinę rodiklių sistemą parodè, kad daugiakriterinius metodus galima sèkmingai naudoti profesinio mokymo istaigoms ranguoti pagal kokybès valdymo rezultataus.

5. Daugiakriteriniais metodais pagrịstą tyrimo modeli galima taikyti ne tik profesinio mokymo istaigu kokybės valdymui ịvertinti. Kriteriju sistema yra tinkama profesinio mokymo kokybès valdymo stebėsenai.

\section{Literatūra}

Beuthe, M.; Scannella, G. 2001. Comparative analysis of UTA multicriteria methods, European Journal of Operational Research 130: 246-262.

Brans, J. P.; Vincke, P. H.; Mareschal, B. 1986. How to select and how to rank projects: The PROMETHEE method, European Journal of Operational Research 24: 228-238.

Fan, Z.; Ma, J.; Tian, P. A 1977. Subjective and objective integrated approach fot the determination of attribute weights, in Materials of 4th Conferense of International Society for Decision Support Systems.

Ginevičius, R.; Podvezko, V. 2001. Complex evaluation of economical-social development of Lithuanian regions, Statyba [Civil Engineering] 7(4): 304-309.

Ginevičius, R., Podvezko, V. 2003. Quantitative evaluation of significance of hierarchically structured indexes, Modelling and Simulation of Business Systems: international conference, May 13-14, 2003, Vilnius, Lithuania / Kaunas University of Technology, Vilnius Gediminas Technical University, Institute of Mathematics and Informatics, Law University of Lithuania, Lithuanian Operational Research Society within EURO (LitORS), The Association of European Operational Research Societies, Baltic Operational Research Society (BaltORS). Kaunas: Technologija, 22-25.

Ginevičius, R.; Podvezko, V.; Mikelis, D. 2004. Quantitative evaluation of economic and social development of Lithuanian regions, Ekonomika: mokslo darbai 65: 67 - 81 .

Ginevičius, R.; Gudačiauskas, D. 2004. Brand valuation model, Journal of Business Economics and Management 5(3): 143-153.

Ginevičius, R.; Podvezko, V.2004a. Determination of weightiness of the hierarchically-structured organization according to its commercial activity, Foundations of Civil and Environmental Engineering. Publishing House of Poznan University of Technology, Poznan, 21-33.

Ginevičius, R.; Podvezko, V. 2004b. Imonių strateginio potencialo kiekybinis ivertinimas, Verslas: teorija ir praktika 5(1): 3-9.

Ginevičius, R.; Podvezko, V. 2005. Daugiakriterinio vertinimo rodikliu sistemos formavimas, Verslas: teorija ir praktika 6(4): 199-207.

Hokkannen, J.; Salminen, P. 1997. ELECTRE III and IV decision aids in an environmental problem, Journal of Multi-Criteria Decision Analysis 5(6): 215-226.

Hwang, C. L.; Yoon, K. 1981. Multiple Attribute Decision Making- 
Methods and Applications. A State of the Art Surwey. Springer Verlag, Berlin, Heidelberg, New York.

Hwang, C. L.; Lin, M. J. 1987. Group Decision Making under Multiple Criteria: Methods and Applications. Springer Verlag, Berlin, Heidelberg, New York.

Larichov, O. I.; Moshkovich, H. M. 1977. Verbal Decision Analysis for Unstructured Problems. Kluwer Academic Publishers Boston.

Opricovič, S.; Tzeng, G.-H. 2004. Compromise solution by MCDM methods: A comparative analysis of VIKON and TOPSIS, EJOR, European Journal of Operational Research 156: 445-455.

Roy, B. 1996. Multicriteria Methodology for Decision Aiding./ Kluwer Academic Publishers Dortrecht.

Ustinovičius, L. 2001. Multi-criteria analysis of the efficiency of construction investments, in Almanach des praktischen Managements in Mitell- und Ost-Europa 3, Nordic Academy of Informatization e.V.i.G. mit Sitz in Stralsund, 4. Quartal 2001, 107-114.

Ustinovičius, L. 2001. Determining integrated weights of attributes, Statyba [Civil Engineering] 7(4): 321-326.
Saaty, T. L. 1994. Fundamentals of Decision Making and Priority Theory with the AHP. RWS Publication, Pittsburgb, PA, USA.

Saaty, T. L. 1980. The Analytic Hierarchy Process. M. Graw-Hill, New York.

Zavadskas, E. K.; Kaklauskas, A. 1996. Pastatų sistemotechninis ivvertinimas. Vilnius: Technika. 280 p.

Zavadskas, E. K.; Kaklauskas, A.; Banaitis, A.; Kvederyte, N. 2004. Housing credit access model: The case for Lithuania, European Journal of Operational Research 155: 335-352.

Бешелев, С. Д.; Гурвич, С. Д. 1974. Математика статистические методы экспертных оценок. Москва: Статистика.

Евланов, Л. Г. 1984. Теория и практика принятия решений. Москва: Экономика.

Завадскас, Э.-К. 1991. Системотехническая оценка технологических решений строительного производства. Ленинград: Стройиздат.

Ларичев, О. И. 1979. Наука и искусство принятия решений. Москва: Наука.

Daiva ANDRIUŠAITIENĖ. Doctor, lector. Department of Social economy and management, Business Management Faculty, Vilnius Gediminas Technical University. Research interests: labor market, depressed regions, labor market vocational training.

Vanda Birutė GINEVIČIENĖ. Master of Educology, Bachelor of the English Language, the director of Language Teaching Center of Vilnius Gediminas Technical University (VGTU).

Algis ŠILEIKA. Doctor habil, Professor. Department of Social economy and management, Business Management Faculty, Vilnius Gediminas Technical University. Research interests: social economy, social policy, living standards, social services, labor market. 